\title{
Spatial Disparity of Rate of Return on Education in Indonesia and Local Spillover Impact in Metropolitan Areas
}

\author{
Yusuf Faisal Martak*, Chotib, Renny Nurhasana \\ Urban Studies Program, School of Strategic and Global Studies, Universitas Indonesia, Central Jakarta, 10430, Indonesia
}

Received November 30, 2020; Revised December 28, 2020; Accepted January 28, 2021

\section{Cite This Paper in the following Citation Styles}

(a): [1] Yusuf Faisal Martak, Chotib, Renny Nurhasana, "Spatial Disparity of Rate of Return on Education in Indonesia and Local Spillover Impact in Metropolitan Areas," Universal Journal of Educational Research, Vol. 9, No. 1, pp. 202 207, 2021. DOI: 10.13189/ujer.2021.090122.

(b): Yusuf Faisal Martak, Chotib, Renny Nurhasana (2021). Spatial Disparity of Rate of Return on Education in Indonesia and Local Spillover Impact in Metropolitan Areas. Universal Journal of Educational Research, 9(1), 202 - 207. DOI: 10.13189/ujer.2021.090122.

Copyright $\bigcirc 2021$ by authors, all rights reserved. Authors agree that this article remains permanently open access under the terms of the Creative Commons Attribution License 4.0 International License

\begin{abstract}
The types of inequality problems in Indonesia are very diverse, one of which is the rate of return on investment in education. To date, this problem has not been resolved by the government. The existence of this imbalance is thought to have a negative effect on the level of welfare of an area where the rate of return is relatively lower. This study aims to see the magnitude of the rate of return on education investment for each district and city in Indonesia. In addition, an analysis of the spatial effect of returns on education investment is also carried out on the level of welfare of an area in adjacent areas. Using the Mincer model to measure the rate of return for each region, the results show that the rate of return on investment in education in all districts and cities in Indonesia varies widely, ranging from $1 \%$ to $11 \%$. Also, spatial analysis using the Spatial Autoregressive model shows that any increase in the percentage of return on investment in education in a certain area will decrease the level of welfare in the surrounding area. The proper regulations specifically related to equality of benefit after getting the education and the ease of migration are needed to overcome each region's negative spillover effect.
\end{abstract}

Keywords Return on Investment in Education, Inequality, Disparity, Spillover Effect, Spatial Impact

\section{Introduction}

Inequality is a common problem that has not been resolved by most countries. In addition, inequality has a significant negative impact on the economy and society. There are several types of inequality that are currently the main problem, for instance, income inequality, access to education and health, to inequality in the use of education that has been taken [15]. According to [12], one of the ways to measure the utilization in education that has been taken is by measuring the rate of return on investment in education. The level of investment in education is a person's decision to invest in the expectation of a return on that investment, especially in the education sector.

The rate of return on investment in education is not the same for every individual, and it depends on the characteristics of the individual itself, regional conditions, and economic status [12]. In addition, there are also several other factors that influence such as the level of education one has, the type of gender, to the type of ordinary high school or vocational school. Moreover, the sector of employment that is acquired after completing education also has a major influence on the rate of return on investment in education [13].

Getting easy access to be able to take advantage of the level of education is a problem in itself. Due to inequality in regional conditions, labor competition, and demands by employers are different for each region. High labor 
competition with a low number of business fields will certainly reduce the return on education investment. Moreover, the types of main sectors in an area that do not require higher education can also reduce the size of the return on education $[7 ; 16]$.

The unequal rate of return on education can have a negative impact on the economy. One of the problems is if there is an area that has a high rate of return and its surroundings are low, there will be a migration event from an area with a low rate of return to a high rate of return [17]. Migration that is manifested as a result of individuals who come from areas with low returns and graduates of good education levels will try to find a higher level of welfare and wages compared to their area of origin.

One area that has the potential to have a negative impact on the inequality of returns on education investment is the metropolitan area. By definition, a metropolitan area is an area that has several characteristics or criteria, such as: (1) Capital or City that is important in an area; (2) Cities or regions that become centers of economic activity, including trade, industry and government [4]. Other than that, reference [2] stated that metropolitan is also included in a city that has a large, complex area, and is also a center for various sectors including the political, cultural and economic sectors. In the case of Indonesia, up to now there are 10 metropolitan areas with 57 districts and cities within them. The concentration of economic activity, industry, and regional development which is much higher than in other surrounding areas makes a difference in the return on education investment in the metropolitan area and beyond.

The general objective of this study is to measure the rate of return on investment in education in each district and city and its impact on surrounding areas, particularly metropolitan areas. Based on these objectives, several analyses will be carried out, namely: (1) estimated rates of return for each Regency and City; (2) estimation of the effect of an increase in the rate of return on education in one area to other regions; (3) analysis of case studies in parts of Indonesian's metropolitan areas.

\section{Data and Methodology}

Data sources \& method of analysis

The data used in this study came from the micro data of the National Socio-Economic Survey (SUSENAS) specifically in the KOR section of March 2019. SUSENAS is survey data from the Indonesian Central Statistics Agency (BPS). There are twice publications of SUSENAS data in one year, in March and September. SUSENAS conducted individual and household surveys of 315,672 and 1,204,466, respectively. SUSENAS data are used in this study on the grounds that the majority of variables in this research come from SUSENAS, such as average length of schooling, work experience, urban and rural residences, and population counts. Based on this explanation, this study uses a quantitative approach through the Mincer model to measure the magnitude of the return on investment in education in each district/city. In addition, this study also tries to analyze the Spatial Autoregressive model to see the impact of the amount of return on investment in education in one area on other areas, especially in metropolitan areas.

\section{Mincer equation}

Mincer equation is one of the most common models used to measure the return on investment individual education. It is done due to its ability to describe the effect of the average percentage return on additional education each year on individual income $(14 ; 5 ; 12]$. In addition, the description of these influences is also the basis of the main function of the Mincer model. On another assumption, because the level of investment in education definitely has a comparison of costs, the only cost indicator that the Mincer model has is work experience [5]. Therefore, the equation for the Mincer model used is:

Equation 1 The Mincer model equation

$$
\begin{array}{r}
\ln \text { earnings }_{i}= \\
\beta_{0}+\beta_{1} \text { yearschooling }_{i}+\beta_{2} \text { Working experience }_{i}+ \\
\beta_{3} \text { Working experience }^{\wedge} 2_{i}+\beta_{n} X+\varepsilon_{i}
\end{array}
$$

In addition to the main variables used in the Mincer model, several control variables will be added so that the estimation results are not biased. This equation is used in estimating the rate of return on education for each district and city in Indonesia.

\section{Spillover effect}

After analyzing the return on education investment in each district and city, this study will also try to conduct a spatial analysis related to the return on investment in education in one region to another. To get the expected analysis, the Spatial Autoregressive model is used to see the spatial impact of the independent variables in an area on the dependent variable in other areas that are close to each other $[8 ; 10]$. The equation used in the SAR model is as follows:

Equation 2 spatial autoregressive mode 1

$$
\begin{gathered}
\text { Dependent variable } \text { va }_{i}=\beta_{0}+\beta_{1} X_{i}++ \text { ? } 1 \sum_{j=1}^{N} W i j * \\
X+\varepsilon_{i}
\end{gathered}
$$

The main difference of the SAR model compared to other linear regression equations is the existence of a matrix of spatial inter-regions. The spatial matrix is used to separate the conditions of a place where the individual in an area compared to other areas so that it can be analyzed how much influence the individual has on other individuals who live differently [11]. According [6], there are various types and ways of spatial weighting, but the 
most commonly used is queen contiguity. Queen contiguity in spatial weighting can define the area which is tangent (represented in the number 1) and does not intersect with the area of origin (represented in the number 0 ). Based on this explanation, the following is an illustration of the spatial weighting matrix used:

Table 1. Spatial Weighted Matrix

\begin{tabular}{|c|c|c|c|c|}
\hline & Region A & Region B & Region C & Region D \\
\hline Region A & 0 & 1 & 0 & 0 \\
\hline Region B & 1 & 0 & 0 & 0 \\
\hline Region C & 0 & 0 & 0 & 1 \\
\hline Region D & 0 & 0 & 1 & 0 \\
\hline
\end{tabular}

Source: Author

Table 1 depicts the spatial weighted matrix in 4 regions. In this case, areas other than the region itself are considered to be intersectional and have an influence on other areas such as region $B$ which affects $A$ and vice versa, and region $C$ which affects $D$ and vice versa. Based on the methodology explanation above, here are the conclusions of the variables and models used:

Table 2. Variables and models used in the analysis

\begin{tabular}{|c|c|c|}
\hline Variable & $\begin{array}{l}\text { Model } 1 \\
\text { Measuring the } \\
\text { rate of return on } \\
\text { education for } \\
\text { each of districts }\end{array}$ & $\begin{array}{c}\text { Model } 2 \\
\text { Local spillover } \\
\text { (expenditure as } \\
\text { dependent } \\
\text { variable) }\end{array}$ \\
\hline \multicolumn{3}{|l|}{$\begin{array}{l}\text { Main variables of } \\
\text { Mincer equation }\end{array}$} \\
\hline Year of schooling & Yes & \\
\hline Work experience & Yes & \\
\hline Work experience $^{\wedge} 2$ & Yes & \\
\hline \multicolumn{3}{|l|}{ Additional variables } \\
\hline Urban $(1$ = yes $)$ & Yes & \\
\hline Male $(1=$ yes $)$ & Yes & \\
\hline Population in 1 district & Yes & Yes \\
\hline \multicolumn{3}{|l|}{$\begin{array}{l}\text { Variable in spatial } \\
\text { modeling (ratio to all } \\
\text { population in } 1 \text { district) }\end{array}$} \\
\hline $\begin{array}{c}\text { Rate of return on } \\
\text { education }\end{array}$ & & Yes \\
\hline Working ratio & & Yes \\
\hline Disability ratio & & Yes \\
\hline Electrification ratio & & Yes \\
\hline Healthcare ratio & & Yes \\
\hline
\end{tabular}

Source: Author
Related to model 1, there is an initial hypothesis that the rate of return on education will be different for each region formed by the conditions of development and education in that area. This assumption is formed following the results of the analysis from previous studies. In model 2, the hypothesis points to the impact of an increase in the rate of return on education on communities' welfare in the surrounding or neighboring areas. This occurs because the surrounding area has a relationship with the area of origin. It has a big influence, especially in the main metropolitan city area in the surrounding area.

\section{Result and Discussion}

Before analyzing the effect of a region's rate of return on other nearby areas, a calculation of the return on investment in education will be carried out in all districts and cities in Indonesia. Using model 1 in table 3, shows the amount of return to education in all districts/cities in Indonesia which significantly increases the average income of individuals. It can be seen that the average rate of return for regencies/municipalities in Indonesia is 5.5\% but the distribution of returns varies widely (Figure 1). Similar with the hypothesis mentioned in pervious chapter, there are high variability of educations' return for each region in Indonesia. There are several regions whose returns are relatively very low compared to other regions, ranging from $1 \%$ to $2 \%$, and there are regions that have rates of up to $12 \%$. This difference in rate of return shows that the use and usefulness of education for each individual is different for each region, depending on how the region has access to use education [14]. The impact of different conditions of education and the ease to get job with good benefit after the education period also provides a difference in the rate of return on education in Indonesia and other countries. Referring to the results obtained, the rate of return on education in Indonesia is still lower than in other countries. Prior to year 2000 and below, the average rate of return on education in the world derived from an analysis of 511 studies using the Mincer equation was $8.7 \%$, while in 2000 and up to 2014 , the average rate of return on education was $9.1 \%$ [14].

Using the existing rate of return, an analysis of the spatial impact of the rate of return on income is carried out. The analysis was carried out by calculating the spatial impact on neighboring areas (model 2 in table 3 ). 


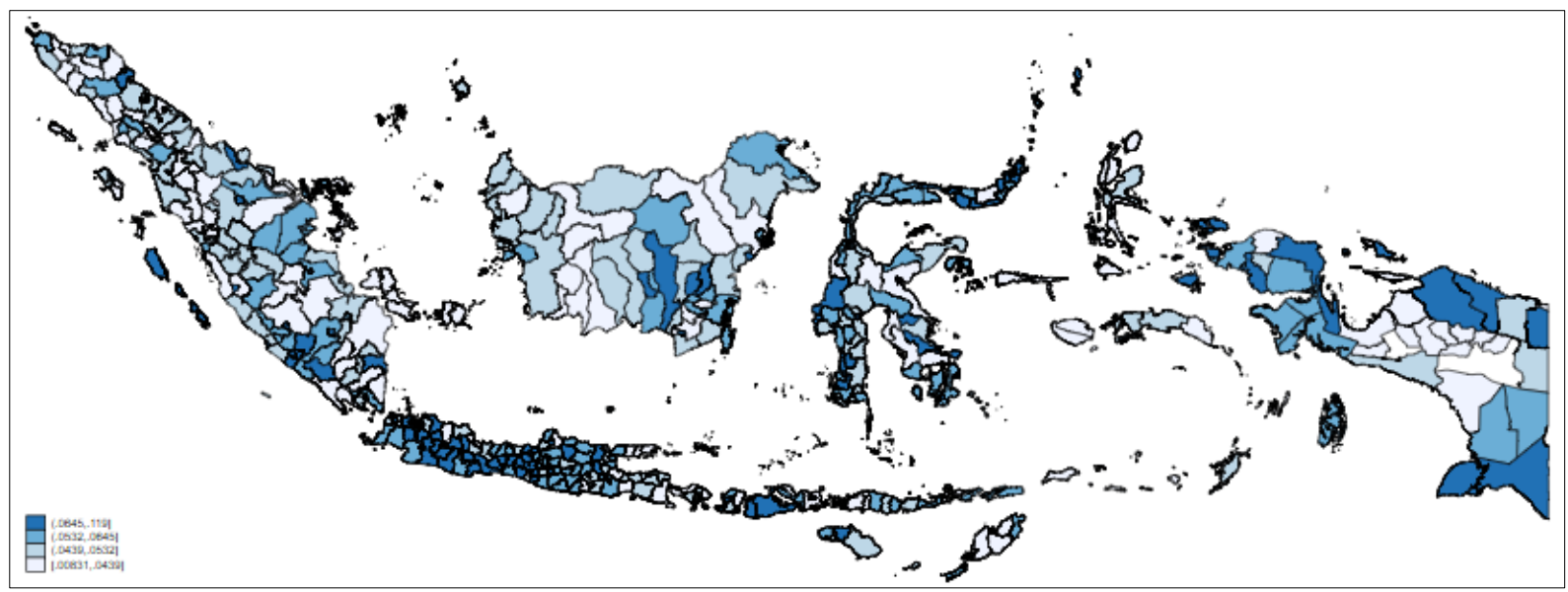

Source: Author

Figure 1. Spatial Pattern of Rate of Return on Education by District / City

Table 3. Results of the regression analysis

\begin{tabular}{|c|c|c|c|c|}
\hline \multirow[t]{2}{*}{ Variable } & \multicolumn{2}{|c|}{ Model 1} & \multicolumn{2}{|c|}{ Model 2} \\
\hline & Coef. & Robust SE & Coef. & SE \\
\hline Year of schooling & $0.055 * * *$ & 0.000 & & \\
\hline Work experience & $0.008 * * *$ & 0.000 & & \\
\hline Work experience $^{\wedge} 2$ & $0.000 * * *$ & 0.000 & & \\
\hline Urban & $0.229 * * *$ & 0.000 & & \\
\hline Male & $0.031 * * *$ & 0.000 & & \\
\hline \multicolumn{5}{|c|}{$\begin{array}{l}\text { Variable in spatial modeling (ratio to all population } \\
\text { in } 1 \text { district) }\end{array}$} \\
\hline Education's return & & & $-3,649 * *$ & $-1,244$ \\
\hline Working ratio & & & -0.096 & 0.201 \\
\hline Disability ratio & & & $-2.54 * * *$ & 0.630 \\
\hline Electrification ratio & & & $0.343 * *$ & 0.136 \\
\hline Population in 1 district & $-0.00 * * *$ & 0.000 & 9.e-09 & $2.80 \mathrm{e}-08$ \\
\hline Healthcare ratio & & & $0.143 *$ & 0.079 \\
\hline Constant & 13.08 & 0.005 & $12.63 * * *$ & 0.166 \\
\hline R-square & \multicolumn{2}{|c|}{0.170} & \multicolumn{2}{|c|}{0.370} \\
\hline Number of Obs & \multicolumn{2}{|c|}{561,213} & \multicolumn{2}{|c|}{492} \\
\hline
\end{tabular}

Robust standard errors in parentheses

*** $\mathrm{p}<0.01, * * \mathrm{p}<0.05, * \mathrm{p}<0.1$

The first stage of the analysis is Moran's test. This test is intended to see whether the exogenous variables used have an influence on the dependent variable in other areas [6; 9]. Similar with the hypothesis of model 2, the results show that the exogenous variables used have a strong influence on variables in other areas. In the analysis of neighboring areas, an increase in the percentage of return to education can significantly reduce the average per capita income of neighboring areas by $3 \%$ on average. The negative impact of the large rate of return on education in other areas is thought to have occurred due to the attractiveness of more prosperous areas to individuals in other areas, which led to the emergence of migration. Generally, migration occurs in individuals who live in areas with a low level of welfare and who move to areas with a better level of welfare [1,3,17]. In this discussion, a more prosperous region is characterized by a high rate of return on investment in education.

Case study: Increase return on investment in education to $10 \%$ in Metropolitan areas

After getting results that show the rate of return to education in Indonesia, it on average has a negative effect on the welfare of other regions. This section will try to 
discuss these returns in the realm of metropolitan areas. The purpose of this analysis is to see how the impact of changes in the rate of return on education investment to $10 \%$ for the center of the metropolitan area on the level of welfare in the surrounding area because this percentage has entered the category of high returns. The metropolitan areas selected in this section are 4 regions representing 4 different islands, namely (1) Medan representing Sumatra Island; (2) DKI Jakarta represents Java Island; (3) Makassar represents Sulawesi Island; (4) Banjarmasin represents Kalimantan Island. In the metropolitan area of Jakarta (figure 2), the change in the rate of return to education in Jakarta to $10 \%$ has resulted in an increase in the welfare level of Jakarta by 0.019 logarithmic units. Meanwhile, there has been a decrease in the level of welfare in all areas around Jakarta which are included in the metropolitan area with a magnitude of 0.004 to 0.047 logarithmic units.

In Makassar (figure 3), the change in the level of welfare for the area of origin is greater than Jakarta, namely 0.093 logarithmic units, this is possible because the rate of return to education in Makassar is lower than that of Jakarta. However, the negative effect on the other surrounding areas is constant at 0.021 logarithmic units. In contrast to Makassar, Banjarmasin (figure 4) has two times greater change in the level of welfare, about 0.185 logarithmic units with an effect to the surrounding area of minus 0.042 logarithmic units. In the area around Banjarmasin, there are two areas that are not affected by changes in the rate of return of Banjarmasin, namely Banjar Baru and Tanah Laut Regency. Medan (figure 5) also has the same pattern as several previous metropolitan areas, increasing the level of welfare in the area of origin by 0.018 logarithmic units and decreasing the area by about 0.004. Similar to Banjarmasin, there are two areas that do not have an impact on changes in the rate of return on education investment in Medan, namely Karo and Binjai.

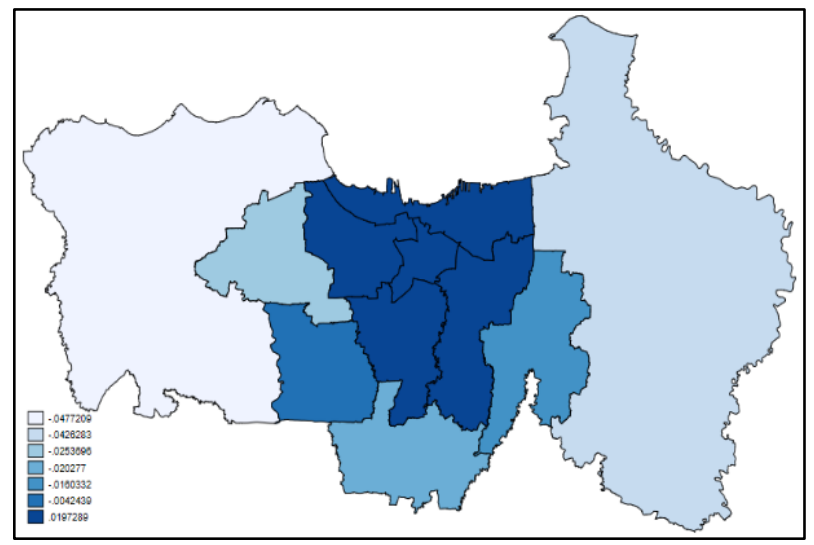

Figure 2. Spillover in Jakarta-Bogor-Depok-Tangerang-Bekasi (Jabodetabek) metropolitan areas

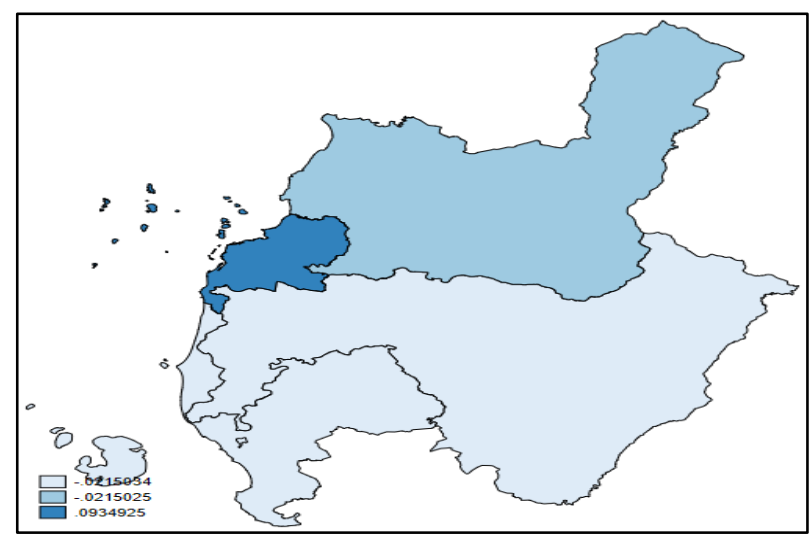

Figure 3. Spillover in Makassar metropolitan areas

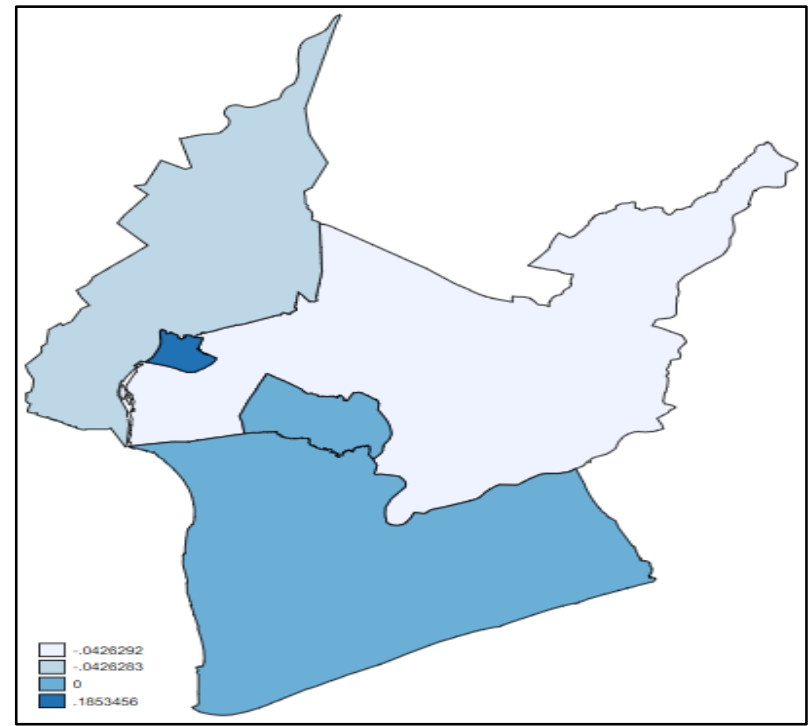

Figure 4. Spillover in Banjarmasin metropolitan areas

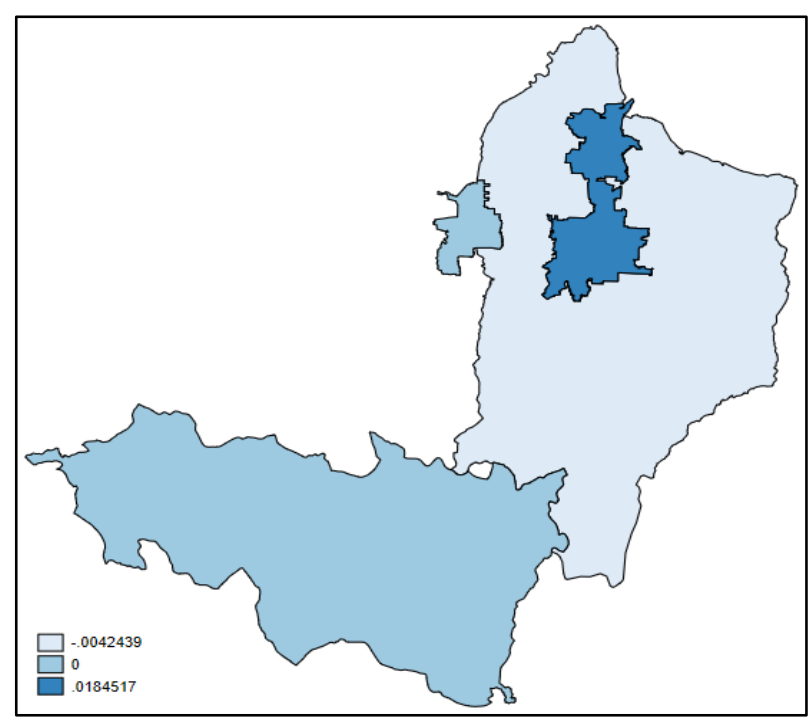

Source: Analysis results

Figure 5. Spillover in Medan metropolitan areas 


\section{Conclusions}

The imbalance in the rate of return on education investment in each district and city is a distinct problem in Indonesia. Similar to other types of inequality, inequality in returns on education investment also has a negative impact on the level of welfare. In general, differences in the rate of return on investment in education are influenced by various factors such as regional conditions, economic level, gender, type of school, and the majority of jobs owned by the region $[12 ; 13]$. The difference in the rate of return on investment in education can have a negative impact on the surrounding areas. This is indicated by the occurrence of migration events from areas with low returns to areas with high returns [17]. For example, individuals who have the same type of diploma and come from areas with different rates of return, will tend to move to areas that have high returns. This is solely done to improve the economic status of these individuals.

In the results of the analysis that has been carried out using the Mincer model, it is found that there is a large imbalance in the rate of return for each district and city in Indonesia. This is indicated by the lowest rate of return of only $1 \%$ compared to the highest rate of return of $11 \%$. In addition, at the next stage of the analysis using the Spatial Autoregressive model, the results show that there is a negative effect on the welfare level of the surrounding area if the area of origin has an increase in the rate of return on education investment. To reduce the negative impact of this inequality event, in the short term, the government provides regulation that focuses on the maximum number of migration from high educations' return area. In the long term, large-scale policies are needed to provide equal distribution of returns in Indonesia such as equalization in wages and ease of getting a job in each of districts/ cities.

\section{Acknowledgement}

We thank Article 33 Indonesia research institute for the financial assistance and data used in this study. Article 33 Indonesia is a research institute engaged in the fields of education, the environment, and the development of vulnerable groups.

\section{REFERENCES}

[1] Addleton, JS. Undermining the Center: The Gulf Migration and Pakistan, International Migration Review, Vol 28. No 3, pp 603-604, 1992. DOI: 10.2307/2546832.

[2] Angotti, T. Planning, Poverty and Politics. Metropolis 2000, 1993.
[3] Azam, F. Labor Migration from Pakistan: Trends, Impacts and Implications. Regional Development Dialogue, 12, 5373, 2001 .

[4] Ministry of Education and Culture's Language Development and Development Agency. What Is Meant By Metropolitan, 2018.

[5] Björklund, A., \& Kjellström, C. Estimating the return to investments in education: How useful is the standard Mincer equation? Economics of Education Review, 21 (3), 195-210, 2002. https://doi.org/10.1016/S0272-7757(01)00003-6.

[6] Chotib, Rouf, A., Yudoyono, A., \& Pamungkas, FD. Department of Geography Faculty of Mathematics and Natural Sciences, University of Indonesia 2019, 2019.

[7] Dello-Iacovo, B. Curriculum reform and "Quality Education" in China: An overview. International Journal of Educational Development, 29 (3), 241-249, 2009. DOI: 10.1016/j.ijedudev.2008.02.008.

[8] Getis, A. Cliff, AD and Ord, JK 1973: Spatial autocorrelation. London: Pawns. Progress in Human Geography, 19 (2), 245-249., 1995.https://doi.org/10.1177/ 030913259501900205.

[9] Huo, XN, Li, H., Sun, DF, Zhou, L. Di, \& Li, BG. Combining geostatistics with moran's i analysis for mapping soil heavy metals in Beijing, China. International Journal of Environmental Research and Public Health, 9 (3), 995-1017, 2012. https://doi.org/10.3390/ijerph9030995.

[10] Kelejian, HH, \& Prucha, IR. Specification and estimation of spatial autoregressive models with autoregressive and heteroskedastic disturbances. Journal of Econometrics, 157 (1), 53-67, 2010.https://doi.org/10.1016/j.jeconom.2009.10 .025 .

[11] Liu, D. How to create animated graphics to illustrate spatial spillover effects, 2018.

[12] Patrinos, H. Estimating the return to schooling using the Mincer equation. IZA World of Labor, (July), 1-11, 2016. https://doi.org/10.15185/izawol.278.

[13] Psacharopoulos, G. Returns to Investment in Education: A Global Update. World Development, 22 (9), 1325-1343, 1994.

[14] Psacharopoulos, G., \& Patrinos, HA. Returns to Investment in Education Result in Singapore and other countries. (April). Retrieved from http://econ.worldbank.org, 2018.

[15] Tilak, JBG. Rates of return to education and income distribution. De Economist, 137 (4), 454-465, 1989. https://doi.org/10.1007/BF01705975.

[16] Wang, F., \& Wu, H. Returns to Education in Rural and Urban China: An Empirical Study. Asian Journal of Social Science Studies, 3 (4), 18, 2018. https://doi.org/10.20849/aj sss.v3i4.499.

[17] Xenogiani, T., Katseli., LT, \& Lucas, REBEFFECTS OF MIGRATION ON SENDING COUNTRIES: WHAT DO WE KNOW? INTERNATIONAL SYMPOSIUM ON INTERNATIONAL MIGRATION AND DEVELOPMENT, (August), 28-30, 2006. 